\title{
CHLORINE DIOXIDE BLEACHING OF PULP FROM CROP RESIDUES: BAGASSE, KASH AND CORN STALKS
}

\author{
TASLIMA FERDOUS, ${ }^{*}$ MD. IMRAN HOSSAIN, ${ }^{*}$ MOUMITA NANJIBA, ${ }^{*}$ \\ M. A. QUAIYYUM* and M. SARWAR JAHAN*** \\ *Department of Applied Chemistry and Chemical Engineering, University of Dhaka, \\ Dhaka 1000, Bangladesh \\ ***Pulp and Paper Research Division, Bangladesh Council of Scientific and Industrial Research \\ Laboratories, Dr. Qudrat-i-Khuda Road, Dhaka 1205, Bangladesh \\ $₫$ Corresponding author: M. Sarwar Jahan, sarwar2065@hotmail.com
}

Received July 10, 2020

This investigation describes the effect of hot chlorine dioxide delignification $\left(\mathrm{D}_{\mathrm{HT}}\right)$ of bagasse, kash and corn stalk pulps on pulp properties and effluent quality. The pulps were subjected to $\mathrm{D}_{\mathrm{HT}}$ at $85{ }^{\circ} \mathrm{C}$ for 45 min and the results were compared with those of the $\mathrm{D}_{0}$ process carried out at $70{ }^{\circ} \mathrm{C}$ for $45 \mathrm{~min}$. The kappa numbers after the alkaline extraction (Ep) stage in $\mathrm{D}_{\mathrm{HT}}$ bleaching were always lower and brightness was higher, compared to the corresponding parameters in $\mathrm{D}_{0}$ bleaching, without impacting pulp viscosity. The final brightness of the corn stalk pulp was $84.8 \%$ at a kappa factor of 0.25 in the $\mathrm{D}_{0}$ process, while in the $\mathrm{D}_{\mathrm{HT}}$ process, the same type of pulp reached the brightness of $87.2 \%$ at a kappa factor of 0.15 , saving $40 \% \mathrm{ClO}_{2}$ in the first stage. Similarly, kash pulp exhibited $90 \%$ brightness at a kappa factor of 0.15 , which also saved $40 \% \mathrm{ClO}_{2}$, compared to the conventional $\mathrm{D}_{0}$ process. The brightness of bagasse pulp in $\mathrm{D}_{\mathrm{HT}}$ and $\mathrm{D}_{0}$ processes was almost similar. Oxygen delignified pulp had a lower effluent discharge than unbleached pulps in subsequent ECF bleaching. The COD value in $\mathrm{D}_{\mathrm{HT}}$ was lower than that in $\mathrm{D}_{0}$.

Keywords: bagasse, kash, corn stalk, high temperature $\mathrm{ClO}_{2}$ bleaching, Kappa number, brightness, COD

\section{INTRODUCTION}

Nowadays, elemental chlorine free (ECF) bleaching is the dominant bleaching technology used for chemical pulp. ${ }^{1}$ Chlorine dioxide $\left(\mathrm{ClO}_{2}\right)$ is a specific oxidizing agent for lignin removal and provides good quality pulp of high brightness, without carbohydrates degradation. ${ }^{2} \mathrm{ClO}_{2}$ has a higher oxidizing potential when compared to $\mathrm{Cl}_{2}$. Molecular chlorine generates substantially more chlorinated organics, particularly aromatics, via electrophilic aromatic substitution reactions, whereas $\mathrm{ClO}_{2}$ reacts via radicals and mainly oxidation, not electrophilic aromatic substitution. This accounts for the reduction in chlorinated aromatics and lower environmental impact of the effluent. ${ }^{3-5}$ However, $\mathrm{ClO}_{2}$ is still enough to pollute the environment. Therefore, many attempts have been made to reduce $\mathrm{ClO}_{2}$ consumption. $^{6-8}$ Studies showed that xylanase, oxygen, peracid or acid treatments improved subsequent $\mathrm{ClO}_{2}$ bleaching. Splitting the $\mathrm{ClO}_{2}$ charge of DED sequences into DEDED sequences increased brightness and reduced the effluent load. ${ }^{6,9}$ Hot acid treatment and $\mathrm{D}_{\mathrm{HT}}$ bleaching have been thoroughly investigated by Ragnar and Lindström, who showed that $\mathrm{D}_{\mathrm{HT}}$ achieved superior results for many of the investigated parameters. ${ }^{10}$ The delignification efficiency of $\mathrm{ClO}_{2}$ in the $\mathrm{D}_{0}$ stage depends on the reaction time and reaction temperature, while reducing the effluent load of bleaching chemicals and also improving the bleached pulp properties. $^{8,11}$ Introducing hot chlorine dioxide $\left(\mathrm{D}_{\mathrm{HT}}\right)$ in ECF bleaching reduced the $\mathrm{ClO}_{2}$ consumption and had a positive impact on bleached pulp properties. Ventorim et al. revealed that a partial acid hydrolysis of hexeneuronic acid (HexA) occurred in $\mathrm{D}_{\text {нт }}$ treatment, resulting in decreased generation of chlorinated organic halides, which is not a possible reaction in $\mathrm{D}_{0}$ with an increase in time and temperature. ${ }^{12}$ Ventorim et al. also found that at a similar $\mathrm{ClO}_{2}$ dose (kappa factor 0.20 at $\mathrm{pH}$ 3.0) in bleaching produced $46.3 \%$ and $9 \%$ less AOX and OX in the filtrate and pulp, respectively, in relation to $\mathrm{D}_{0}{ }^{12}$ 
Brogdon in his review showed that hot Astages, when applied ahead of ECF bleaching, can reduce the amount of HexA entering into the bleach plant by 30 to $90 \%$ and some lignin was removed as well. ${ }^{13}$ Most applications of hot Astages are combined with $\mathrm{D}_{0}$ into a single operation, $\left(\mathrm{A} / \mathrm{D}_{0}\right)$ or "hot $\mathrm{D}_{0}$-Stage." These processes can be very effective in decreasing the amount of $\mathrm{ClO}_{2}$ required for ECF bleaching of hardwood pulps (20 to 50\%).

Buchert et al. showed that, when bleaching with chlorine dioxide, the HexA side groups of pulp xylan were degraded, whereas the MeGlcA and arabinose side groups were relatively stable toward the bleaching chemicals. ${ }^{14}$ The hydrolysis of HexA occurs rapidly at high temperature and low $\mathrm{pH}$, and it can be removed easily from the pulp. ${ }^{15}$ This lowers the consumption of chemicals during bleaching, leading to lower generation of chlorolignin compounds. The studies revealed that the $\mathrm{D}_{\mathrm{HT}}$ stage is able to dissociate the phenolic lignin and HexA, and to limit the generation of organochlorides. ${ }^{15-17}$ Much research has been carried out on $\mathrm{D}_{\mathrm{HT}}$ in the initial stage of bleaching of hardwood pulp, but the literature available on non-wood/agricultural residues pulps is scarce. . $^{10,12,19-21}$

Most of the studies used a temperature of 95 ${ }^{\circ} \mathrm{C}$ for longer time, and consequently obtained reduced viscosity and a slight drop in final pulp brightness. The lower brightness obtained after $\mathrm{D}_{\mathrm{HT}} \mathrm{E}$ is explained by the brightness reversion reactions caused by maintaining the pulp at high temperature/time in the complete absence of chlorine dioxide (Eiras et al.). ${ }^{22}$ The hot acid treatment also formed new lignin phenolic hydroxyl groups, which may form new chromophores. ${ }^{23}$ Therefore, the purpose of the present study was to use $\mathrm{ClO}_{2}$ treatment at higher than conventional temperature $\left(70{ }^{\circ} \mathrm{C}\right)$ and lower than $95{ }^{\circ} \mathrm{C}$, in order to reduce $\mathrm{ClO}_{2}$ consumption and effluent load, while achieving improved brightness.

In this study, $\mathrm{D}_{\mathrm{HT}}$ bleaching of crop residue pulps obtained from bagasse, kash and corn stalks was carried out at $85^{\circ} \mathrm{C}$ for a short time, and the results were compared with those of $\mathrm{D}_{0}$ bleaching. The final pulp properties and the effluent quality were also studied.

\section{EXPERIMENTAL \\ Materials}

Pulps from bagasse, kash and corn stalks were prepared in the laboratory by the soda-AQ process.
The cooking experiment was conducted in an electrically heated, thermostatically controlled digester of 20 litre capacity. $1 \mathrm{~kg}$ of crop residues was used for all the experiments. All three types of crop residues were cooked with $18 \%$ alkali charge and $0.1 \%$ AQ for $2 \mathrm{~h}$ at $150{ }^{\circ} \mathrm{C}$. The material to liquor ratio was 1:6.

\section{Oxygen delignification}

Oxygen delignification (OD) was carried out in a thermostatically controlled digester, rotating at $1 \mathrm{rpm}$. The OD conditions were as follows: $110{ }^{\circ} \mathrm{C}$, retention time $60 \mathrm{~min}$, pulp consistency $10 \%, \mathrm{NaOH} 2 \%$, $\mathrm{MgSO}_{4} 0.3 \%$ and $\mathrm{O}_{2}$-pressure $3.5 \mathrm{~kg} . \mathrm{cm}^{-2}$.

\section{Evaluation of pulps}

The kappa number, viscosity, brightness and HexA of the resulting pulps in unbleached and oxygen delignified state were determined in accordance with Tappi Test Methods, namely, kappa number (T 236 om-99), pulp viscosity (T 230 om-99), pulp ISO brightness ( $\mathrm{T} 452$ om-92) and hexenuronic acid content (T282 pm-07). Three replicates of all the experiments were performed, and the average reading was taken.

\section{$\mathrm{D}_{\mathbf{0}}(\mathbf{E p}) \mathrm{D}_{1}$ and $\mathrm{D}_{\mathrm{HT}}(\mathrm{Ep}) \mathrm{D}_{\mathbf{1}}$ bleaching}

Unbleached and oxygen delignified pulps were bleached by $\mathrm{D}_{0}(\mathrm{Ep}) \mathrm{D}_{1}$ and $\mathrm{D}_{\mathrm{HT}}(\mathrm{Ep}) \mathrm{D}_{1}$ bleaching sequences (where D represents chlorine dioxide and (Ep) represents peroxide reinforced alkaline extraction). The chlorine dioxide charge in the $\mathrm{D}_{0}$ and $\mathrm{D}_{\text {Hт }}$ stages was varied by kappa factor of $0.15,0.2$ and 0.25 . The temperature was $70^{\circ} \mathrm{C}$ in the $\mathrm{D}_{0}$ stage for 45 min. Pulp consistency was $10 \%$. The $\mathrm{pH}$ was adjusted to 2.5 by adding dilute $\mathrm{H}_{2} \mathrm{SO}_{4}$. In the $\mathrm{D}_{\text {Нт }}$ stage, the bleaching temperature was $85{ }^{\circ} \mathrm{C}$ and all the other parameters remained the same. The alkaline extraction stage was performed under the following conditions: temperature of $70{ }^{\circ} \mathrm{C}$ for $60 \mathrm{~min}$, a water solution of $2 \% \mathrm{NaOH}$ and $0.5 \% \mathrm{H}_{2} \mathrm{O}_{2}$ (on o.d. pulp). After the (Ep) stage, kappa number, viscosity and brightness were determined in accordance with Tappi Test Methods, as mentioned above.

In the $\mathrm{D}_{1}$ stage, the $\mathrm{pH}$ was adjusted to obtain a final $\mathrm{pH}$ of 4.5. The $\mathrm{ClO}_{2}$ charge in the $\mathrm{D}_{1}$ stage was fixed to $1 \%$. The brightness and viscosity of the bleached pulp, as well as COD of the mixed effluent collected from the $\mathrm{D}_{0}, \mathrm{E}_{\mathrm{p}}$ and $\mathrm{D}_{1}$ stages, were determined in accordance with PAPTAC Methods H.3.

\section{RESULTS AND DISCUSSION}

Table 1 shows the basic properties of the starting pulps obtained from bagasse, kash and corn stalks. Oxygen delignification reduced the kappa number by $40.7 \%, 51.3 \%$ and $31.6 \%$ and increased the brightness by $24.59 \%, 30.33 \%$ and $7.2 \%$ ISO points for bagasse, kash and corn stalk 
pulps, respectively. However, the pulp viscosities were not changed significantly.

\section{$D_{\mathrm{HT}}(\mathrm{Ep})$ and $\mathrm{D}_{\mathbf{0}}(\mathrm{Ep})$ pulp properties}

The effect of kappa factor on residual $\mathrm{ClO}_{2}$, (Ep) kappa number, brightness and viscosity are shown in Table 2. As shown in Table 2, the residual $\mathrm{ClO}_{2}$ in conventional $\mathrm{D}_{0}$ was found to be of 66-158 ppm for bagasse, 60-100 ppm for kash and 54-82 ppm for corn stalk unbleached pulps, which decreased significantly in the $\mathrm{D}_{\mathrm{HT}}$ treatment. The residual $\mathrm{ClO}_{2}$ was found to be lower than for the unbleached pulp and nil for the oxygen delignified kash pulp after $\mathrm{D}_{\text {Нт }}$ bleaching, where a lower dose of $\mathrm{ClO}_{2}$ was used. At higher temperature in $\mathrm{D}_{\mathrm{HT}}$, most of the $\mathrm{ClO}_{2}$ was consumed during bleaching and its effect was also reflected in the kappa number measurement after the (Ep) stage.

As expected, an increasing kappa factor resulted in a decreased kappa number and viscosity, as well as increased brightness, in both $\mathrm{D}_{0}$ and $\mathrm{D}_{\mathrm{HT}}$ processes. $\mathrm{D}_{\mathrm{HT}}$ bleaching is more efficient than $\mathrm{D}_{0}$ and supported a reduction of the chlorine dioxide dose during bleaching (Table 2). The kappa number after the (Ep) stage decreased with increasing kappa factor and oxygen delignification. The kappa numbers after the (Ep) stage in $\mathrm{D}_{\mathrm{HT}}$ bleaching were always lower than in $\mathrm{D}_{0}$ bleaching. This is related to the acid leaching of lignin, as described and reported in earlier studies. ${ }^{17,24}$ For pulp bleaching at a kappa factor of 0.2, the (Ep) kappa numbers were 2.4 and 1.4 for bagasse, 1.2 and 0.9 for kash and 2.5 and 2.1 for corn stalks, for unbleached and oxygen delignified pulps, respectively, which further decreased upon $\mathrm{D}_{\mathrm{HT}}$ to 1.4 and 0.7 for bagasse, 0.9 and 0.8 for kash and 1.8 and 1.6 for corn stalks. The higher kappa number decrease in the $\mathrm{D}_{\mathrm{HT}}(\mathrm{Ep})$ stage, as compared to the $\mathrm{D}_{0}(\mathrm{Ep})$ one, can be explained by the higher removal of HexA. ${ }^{25}$ This can also be explained by the degradation of hemicelluloses during the $\mathrm{D}_{\mathrm{HT}}$ treatment, which breaks down the bonds of the lignin-carbohydrate complex (LCC) and increases the extraction of the lignin from the surface of the fiber, as described by Zhang and coworkers. ${ }^{26}$ On the other hand, according to Ikeda et al., the temperatures are not high enough to cleave the $\mathrm{C}$ $\mathrm{O}$ or $\mathrm{C}-\mathrm{C}$ bonds that link lignin to carbohydrates in LCC. ${ }^{17}$ McDonough and co-workers speculated that the proportion of HexA contributing to the pulp's kappa number entering the $\mathrm{D}_{0}$ stage affected the bleachability of a red oak pulp that underwent hot acid hydrolysis. ${ }^{27}$

Pulp brightness after the $\mathrm{D}_{0}(\mathrm{Ep}) / \mathrm{D}_{\mathrm{HT}}(\mathrm{Ep})$ stage is also shown in Table 2 and Figure 1 (a, b and c). Oxygen delignified pulp showed better pulp brightness than the unbleached pulp, regardless of $\mathrm{D}_{0}$ or $\mathrm{D}_{\mathrm{HT}}$ bleaching. The brightness of $\mathrm{D}_{0}$ treated pulps was better than that of the pulps treated by the $\mathrm{D}_{\mathrm{HT}}$ process using an identical amount of chlorine dioxide (Fig. 1). As shown in Figure 1, the higher brightness advantage in the $\mathrm{D}_{\mathrm{HT}}$ stage than in the $\mathrm{D}_{0}$ stage after the (Ep) stage was of $3 \%$ for corn stalks and kash unbleached pulps. Ventorim et al. found the first chlorine dioxide stage at high temperature $\left(\mathrm{D}_{\mathrm{HT}}\right)$ decreased the brightness by $2.5 \%$ ISO and kappa number by $46 \%$ (1.9 units) in the extraction stage, as compared to the conventional D stage. ${ }^{12}$ Their results were also in agreement with other findings. ${ }^{10,22}$ The target of this study was to improve brightness and kappa number reduction at $85{ }^{\circ} \mathrm{C}$ for shorter bleaching time, which was achieved.

As shown in Table 2, oxygen delignification reduced pulp viscosity significantly. There was no significant change in post-extraction pulp viscosity after $D_{\mathrm{HT}}$ bleaching. However, other studies showed that the $\mathrm{D}_{\mathrm{HT}} \mathrm{E}$ treatment at $95{ }^{\circ} \mathrm{C}$ resulted in a significant drop in post-extraction pulp viscosity, as compared to the DE one. ${ }^{17,28} \mathrm{~A}$ slight carbohydrate hydrolysis may occur when the pulp is exposed to high time/temperature reaction and acidic $\mathrm{pH}$. The significant viscosity loss is related to the hot acid hydrolysis of the carbohydrates at $2.5 \mathrm{pH}^{12,15,29}$ 
TASLIMA FERDOUS et al.

Table 1

Pulp properties of unbleached and oxygen delignified pulps from bagasse, kash and corn stalks

\begin{tabular}{|c|c|c|c|c|c|c|c|c|}
\hline \multirow{2}{*}{ Pulp } & \multicolumn{2}{|c|}{ Kappa number } & \multicolumn{2}{|c|}{ Viscosity (mPa.s) } & \multicolumn{2}{|c|}{ HexA $(\mu$ mole $/ g)$} & \multicolumn{2}{|c|}{ Brightness (\%) } \\
\hline & Unbleached & $\mathrm{O}_{2}$-delignified & Unbleached & $\mathrm{O}_{2}$-delignified & Unbleached & $\mathrm{O}_{2}$-delignified & Unbleached & $\mathrm{O}_{2}$-delignified \\
\hline Bagasse & 14.3 & 8.5 & 15.1 & 15.5 & 25.9 & 26.1 & 27.9 & 52.5 \\
\hline Kash & 14.8 & 7.2 & 13.9 & 12.2 & 21.2 & 22.7 & 21.1 & 51.4 \\
\hline Corn stalks & 10.0 & 8.2 & 33.6 & 32.3 & 31.2 & 30.5 & 21.4 & 28.6 \\
\hline
\end{tabular}

Table 2

Effect of $\mathrm{D}_{\mathrm{HT}}$ and $\mathrm{D}_{0}$ bleaching on pulp properties after (Ep) stage

\begin{tabular}{|c|c|c|c|c|c|c|c|c|c|c|}
\hline \multirow{2}{*}{ Pulp } & \multirow{2}{*}{ Temp. } & \multirow{2}{*}{ Kappa factor } & \multicolumn{2}{|c|}{ Residual $\mathrm{ClO}_{2}(\mathrm{ppm})$} & \multicolumn{2}{|c|}{ Kappa No } & \multicolumn{2}{|c|}{ Brightness (\%) } & \multicolumn{2}{|c|}{ Viscosity (mPa.s) } \\
\hline & & & UB & $\mathrm{OB}$ & UB & $\mathrm{OB}$ & UB & $\mathrm{OB}$ & UB & $\mathrm{OB}$ \\
\hline \multirow{6}{*}{ 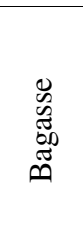 } & \multirow{3}{*}{70} & 0.15 & 66 & 55 & 2.6 & 1.4 & 69.43 & 70.31 & 18.4 & 16.57 \\
\hline & & 0.2 & 105 & 68 & 2.4 & 1.4 & 70.76 & 72.51 & 18.5 & 16.49 \\
\hline & & 0.25 & 158 & 73 & 2.0 & 1.2 & 71.00 & 72.96 & 18.9 & 16.12 \\
\hline & \multirow{3}{*}{85} & 0.15 & 67 & 50 & 1.8 & 1.2 & 70.10 & 72.41 & 18.7 & 14.50 \\
\hline & & 0.2 & 67 & 61 & 1.4 & 0.7 & 73.92 & 73.28 & 17.8 & 15.24 \\
\hline & & 0.25 & 68 & 62 & 0.8 & 0.7 & 76.85 & 75.51 & 16.5 & 10.79 \\
\hline \multirow{6}{*}{$\begin{array}{l}\tilde{I} \\
\tilde{\Xi} \\
\check{v}\end{array}$} & \multirow{3}{*}{70} & 0.15 & 100 & 54 & 1.6 & 1.1 & 66.0 & 84.20 & 14.4 & 11.07 \\
\hline & & 0.2 & 110 & 60 & 1.2 & 0.9 & 82.0 & 85.35 & 15.4 & 12.74 \\
\hline & & 0.25 & 112 & 64 & 0.7 & 0.7 & 84.38 & 85.5 & 13.5 & 13.05 \\
\hline & \multirow{3}{*}{85} & 0.15 & 65 & nil & 1.4 & 0.9 & 81.09 & 83.10 & 14.4 & 10.8 \\
\hline & & 0.2 & 67 & nil & 0.9 & 0.8 & 84.48 & 85.15 & 14.6 & 10.2 \\
\hline & & 0.25 & 82 & nil & 0.8 & 0.7 & 85.02 & 86.2 & 13.9 & 10.7 \\
\hline \multirow{6}{*}{ 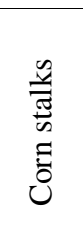 } & \multirow{3}{*}{70} & 0.15 & 54 & 52 & 3.5 & 2.3 & 66.9 & 83.4 & 22.8 & 18.7 \\
\hline & & 0.2 & 74 & 62 & 2.5 & 2.1 & 82.29 & 85.2 & 22.6 & 18.2 \\
\hline & & 0.25 & 82 & 74 & 1.8 & 1.5 & 83.6 & 85.52 & 23.0 & 18.4 \\
\hline & \multirow{3}{*}{85} & 0.15 & 45 & 34 & 2.1 & 2.0 & 76.03 & 80.58 & 22.5 & 18.6 \\
\hline & & 0.2 & 64 & 57 & 1.8 & 1.6 & 83.1 & 83.4 & 22.1 & 18.2 \\
\hline & & 0.25 & 74 & 64 & 1.3 & 1.1 & 84.2 & 86.75 & 21.4 & 18.0 \\
\hline
\end{tabular}




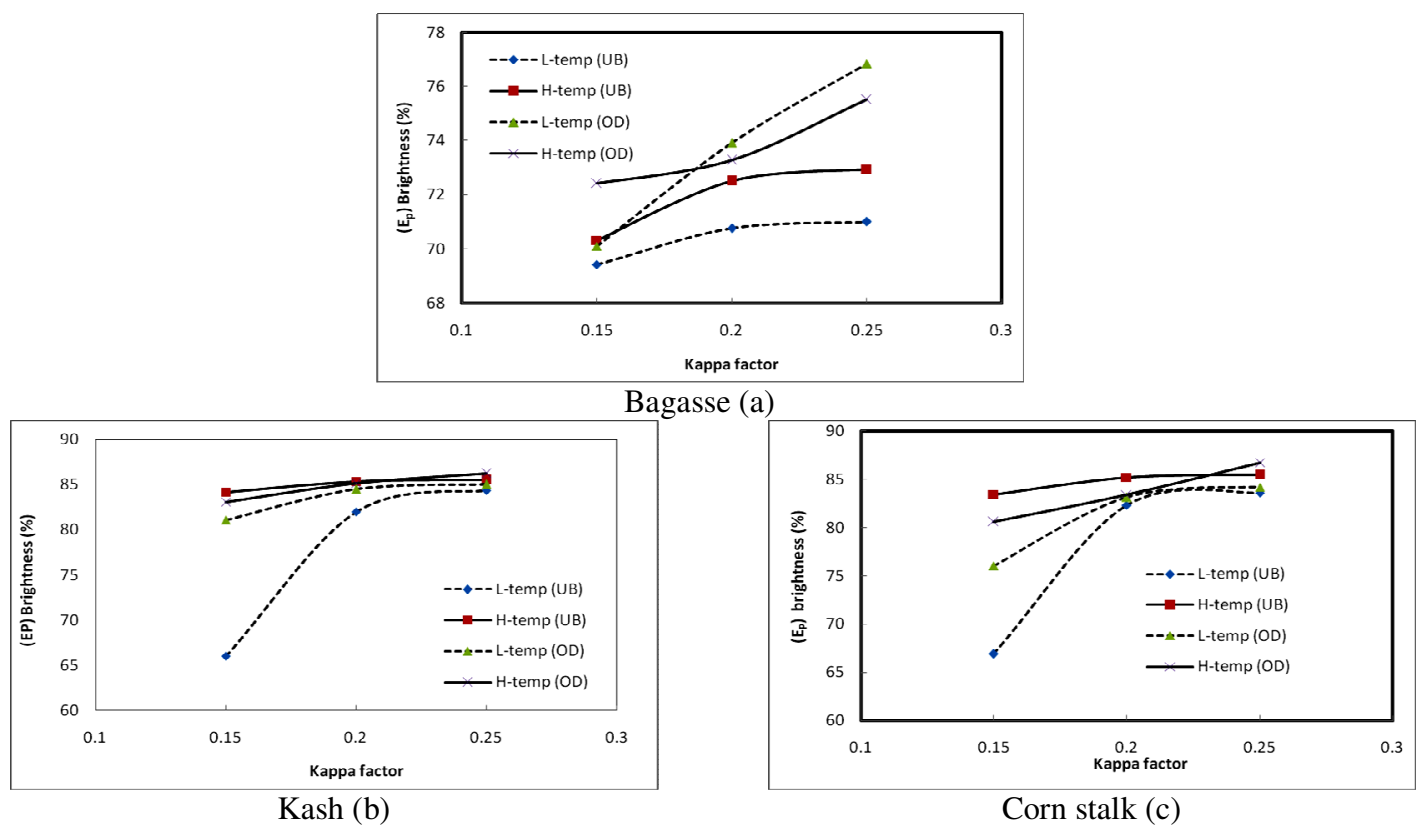

Figure 1: Effect of $\mathrm{D}_{\mathrm{HT}}$ and $\mathrm{D}_{0}$ bleaching on (Ep) brightness

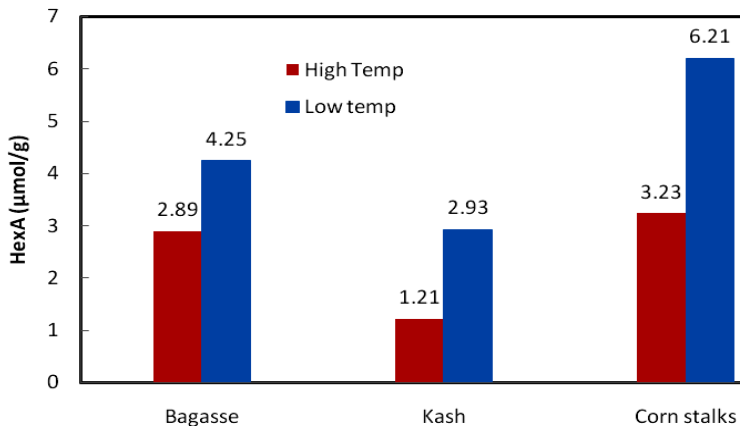

Figure 2: Residual HexA of final pulp

\section{$D_{H T}(E p) D_{1}$ and $D_{0}(E p) D_{1}$ pulp properties}

The effect of the $\mathrm{D}_{\mathrm{HT}}$ on the residual HexA was also studied and shown Figure 2. The residual HexA content in $D_{\text {HT }}$ bleached pulps was much lower than in the $\mathrm{D}_{0}$ pulps. At a kappa factor of 0.2 , the residual HexA contents were 4.25, 2.93 and $6.21 \mu \mathrm{mol} / \mathrm{g}$ for the $\mathrm{D}_{0}$ pulps, and $2.89,1.21$ and $3.23 \mu \mathrm{mol} / \mathrm{g}$ for the $\mathrm{D}_{\mathrm{HT}}$ pulps from bagasse, kash and corn stalks, respectively. This is explained by the degradation of HexA in the $\mathrm{D}_{\mathrm{HT}}$ process. HexA could not react with chlorine dioxide, but reacted with its intermediates, such as hypochlorous acid and molecular chlorine, ${ }^{30,31}$ therefore increased chlorine dioxide consumption and affected pulp bleachability.

As shown in Figure 3, the COD value of the combined effluent from the $\mathrm{D}_{0}$, Ep and $\mathrm{D}_{1}$ stages in $\mathrm{D}_{\mathrm{HT}}(\mathrm{Ep}) \mathrm{D}_{1}$ bleaching was lower than that of the effluent from $\mathrm{D}_{0}(\mathrm{Ep}) \mathrm{D}_{1}$. Oxygen delignified pulp always exhibited a lower COD load in the effluent. The $\mathrm{D}_{\mathrm{HT}}$ process at a kappa factor of 0.2 decreased the COD value from $1120 \mathrm{mg} / \mathrm{L}$ to $1060 \mathrm{mg} / \mathrm{L}$ and from $1040 \mathrm{mg} / \mathrm{L}$ to $760 \mathrm{mg} / \mathrm{L}$ for bagasse pulp, from $1044 \mathrm{mg} / \mathrm{L}$ to $860 \mathrm{mg} / \mathrm{L}$ and from $828 \mathrm{mg} / \mathrm{L}$ to $700 \mathrm{mg} / \mathrm{L}$ for kash pulp, and from $1270 \mathrm{mg} / \mathrm{L}$ to $1011 \mathrm{mg} / \mathrm{L}$ and from 717 $\mathrm{mg} / \mathrm{L}$ to $558 \mathrm{mg} / \mathrm{L}$ for corn stalk pulp, for unbleached and oxygen delignified pulps, respectively. Similar COD value reductions were reported in other studies. ${ }^{32}$

Although pulp brightness after the (Ep) stage was higher in oxygen delignified pulp, the final pulp brightness of unbleached and oxygen delignified pulps was almost similar. Also, the final brightness of the pulp that underwent the $\mathrm{D}_{\mathrm{HT}}$ process was better or similar to that of the pulp subjected to conventional $\mathrm{D}_{0}$. 
Table 3

Effect of $\mathrm{D}_{\mathrm{HT}}$ and $\mathrm{D}_{0}$ bleaching on final pulp properties

\begin{tabular}{|c|c|c|c|c|c|c|}
\hline \multirow{2}{*}{ Pulp } & \multirow{2}{*}{ Temp. } & \multirow{2}{*}{$\begin{array}{l}\text { Kappa } \\
\text { factor }\end{array}$} & \multicolumn{2}{|c|}{ Brightness (\%) } & \multicolumn{2}{|c|}{ Viscosity (mPa.s) } \\
\hline & & & UB & OD & UB & OD \\
\hline \multirow{6}{*}{ 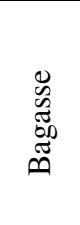 } & \multirow{3}{*}{70} & 0.15 & 87.2 & 86.0 & 14.85 & 13.0 \\
\hline & & 0.2 & 89.1 & 87.1 & 14.2 & 12.5 \\
\hline & & 0.25 & 89.3 & 89.1 & 13.12 & 11.4 \\
\hline & \multirow{3}{*}{85} & 0.15 & 85.6 & 85.0 & 12.7 & 12.6 \\
\hline & & 0.2 & 89.3 & 88.6 & 12.5 & 11.1 \\
\hline & & 0.25 & 89.2 & 88.3 & 12.1 & 11.5 \\
\hline \multirow{6}{*}{ 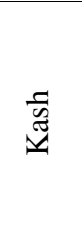 } & \multirow{3}{*}{70} & 0.15 & 83.0 & 87.0 & 14.79 & 10.45 \\
\hline & & 0.2 & 88.6 & 90.4 & 14.2 & 10.49 \\
\hline & & 0.25 & 89.0 & 90.2 & 14.24 & 13.23 \\
\hline & \multirow{3}{*}{85} & 0.15 & 90.0 & 89.6 & 11.03 & 10.5 \\
\hline & & 0.2 & 90.2 & 90.0 & 10.8 & 10.2 \\
\hline & & 0.25 & 90.5 & 90.9 & 10.5 & 10.0 \\
\hline \multirow{6}{*}{ 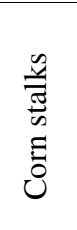 } & \multirow{3}{*}{70} & 0.15 & 83.5 & 83.8 & 15.3 & 14.5 \\
\hline & & 0.2 & 83.7 & 83.7 & 15.5 & 14.8 \\
\hline & & 0.25 & 84.8 & 84.7 & 15.2 & 14.2 \\
\hline & \multirow{3}{*}{85} & 0.15 & 87.2 & 87.8 & 13.7 & 12.5 \\
\hline & & 0.2 & 87.1 & 87.9 & 13.5 & 12.7 \\
\hline & & 0.25 & 87.4 & 87.7 & 13.5 & 12.4 \\
\hline
\end{tabular}

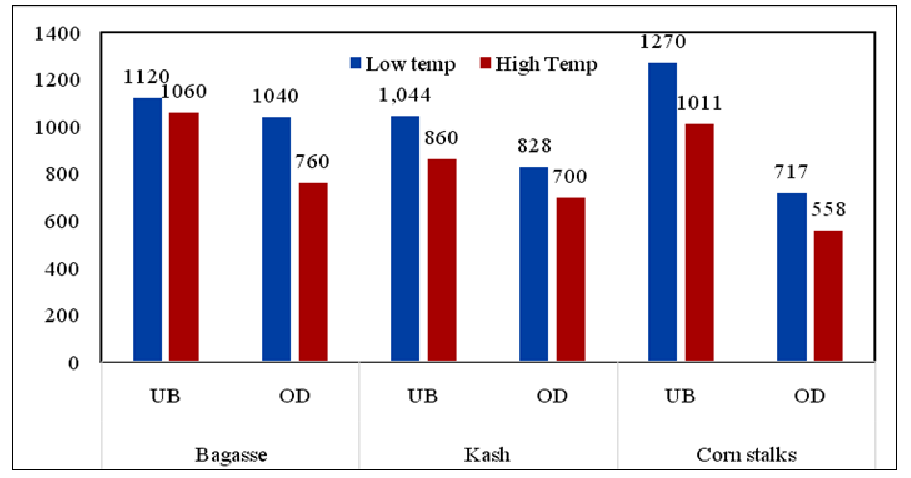

Figure 3: Effect of $\mathrm{D}_{\mathrm{HT}}$ and $\mathrm{D}_{0}$ bleaching on COD value after final stage

Unbleached corn stalk pulp produced a final brightness of $84.8 \%$ at a kappa factor of 0.25 in the $\mathrm{D}_{0}$ process, while in the $\mathrm{D}_{\mathrm{HT}}$ process, it achieved a brightness of $87.2 \%$ at a kappa factor of 0.15 , and saved $40 \% \mathrm{ClO}_{2}$ in the first stage. Similarly, kash pulp exhibited $90 \%$ brightness at a kappa factor of 0.15 , and also saved $40 \% \mathrm{ClO}_{2}$, compared to the conventional $\mathrm{D}_{0}$ process. The brightness of bagasse pulp in $\mathrm{D}_{\mathrm{HT}}$ and $\mathrm{D}_{0}$ processes was almost similar, which has been one of our targets in this study. Kumar et al. ${ }^{11}$ showed that the use of $\mathrm{D}_{\mathrm{HT}}$ reduced by $15 \%$ the $\mathrm{ClO}_{2}$ requirement and improved pulp brightness and brightness stability, in comparison with the reference sequences $D_{0}$. In another study, it was observed that the final pulp brightness was directly correlated with the percentage of HexA removal during $\mathrm{D}_{\mathrm{HT}}{ }^{33}$

\section{CONCLUSION}

Bagasse, kash and corn stalk pulps were bleached by hot chlorine dioxide bleaching. In the first stage, bleaching at $85{ }^{\circ} \mathrm{C}$ for $45 \mathrm{~min}\left(\mathrm{D}_{\mathrm{HT}}\right)$ produced pulp with a lower kappa number, higher brightness and similar viscosity after the (Ep) stage, compared to the same parameters achieved after the conventional $\mathrm{D}_{0}$ stage. The final pulp brightness reached $87.2 \%$ for corn stalk pulp and $90.0 \%$ for kash pulp, i.e. higher than the values obtained in $\mathrm{D}_{0}$ bleaching, while using $40 \%$ less $\mathrm{ClO}_{2}$. The $\mathrm{COD}$ values and residual HexA content in the $\mathrm{D}_{\mathrm{HT}}$ bleached pulps were much lower than those of the $\mathrm{D}_{0}$ pulps. Therefore, $\mathrm{D}_{\mathrm{HT}}$ bleaching at $85{ }^{\circ} \mathrm{C}$ for $45 \mathrm{~min}$ improved the brightness of bagasse, kash and corn stalk pulps, while diminishing the effluent load. 
ACKNOWLEDGEMENT: The authors wish to thank Bangladesh Council of Scientific and Industrial Research for providing the necessary funds to carry out this research.

\section{REFERENCES}

M. Verta, J. Ahtiainen, T. Nakari, A. Langi and E. Talka, in "Environmental Fate and Effects of Pulp and Paper Mill Effluents", edited by M. R. Servos, K. R. Munkittrick, J. H. Carey and G. J. Van Der Kraak, St. Lucie Press, Florida, 1996, pp. 41-52

2 B. Bouiri and M. Amrani, Fibres Text. East. Eur., 19 , 142

(2011),

http://www.fibtex.lodz.pl/article556.html

3 D. Kaur, N. K. Bhardwaj and R. K. Lohchab, J. Clean Prod., 170, $174 \quad$ (2018), https://doi.org/10.1016/j.jclepro.2017.09.111

4 S. Nie, Z. Wu, J. Liu, X. Liu, C. Qin et al., Appita J., $\quad$ 66, $306 \quad$ (2013), https://search.informit.org/doi/10.3316/INFORMIT.62 5213273612519

5 S. Nie, S. Yao, C. Qin, K. Li, X. Liu et al., BioResources, 9, $5604 \quad$ (2014), https://bioresources.cnr.ncsu.edu/resources/kinetics-ofaox-formation-in-chlorine-dioxide-bleaching-ofbagasse-pulp

6 M. S. Jahan, M. M. Uddin and M. A. Kashem, Bangladesh J. Sci. Ind. Res., 52, 247 (2017), https://doi.org/10.3329/bjsir.v52i4.34812

M. Haque, M. Nanjiba, M. S. Jahan, M. A. Quaiyyum, M. Z. Alam et al., Nord. Pulp Paper Res. J., 34, 165 (2019), https://doi.org/10.1515/npprj-20180082

8 S. Nie, S. Wang, C. Qin, S. Yao, J. F. Ebonka et al., Bioresour. Technol., 196, 413 (2015), https://doi.org/10.1016/j.biortech.2015.07.115

9 C. Chirat, D. Lachenal and G. Mortha, in Procs. Tappi Pulping Conference, Tappi Press, Atlanta GA, USA, 2000, https://www.tappi.org

10 M. Ragnar and M. Lindström, Рар. Рии, 86, 39 (2004)

11 S. Kumar, S. P. Mishra, O. P. Mishra, P. Bajpai, S. Tripathi et al., Ippta J., 19, 87 (2007)

12 G. Ventorim, J. L. Colodette and K. M. Eiras, Nord. Pulp Paper Res. J., 20, 7 (2005), https://doi.org/10.3183/npprj-2005-20-01-p007-011

13 B. N. Brogdon, in Procs. TAPPI Engineering, Pulping and Environmental Conf., TAPPI PRESS, Atlanta, GA, USA, 2009

14 J. Buchert, A. Teleman, V. Harjunpaa, M. Tenkanen, L. Vikari et al., Tappi J., 78, 125 (1995)

15 G. Ventorim, J. L. Colodette, A. F. Gomes and L. H. Mandes de Silva, Wood Fiber Sci., 40, 190 (2008), https://wfs.swst.org/index.php/wfs/article/view/1693
16 M. Bjorklund, U. Germgard and J. Basta, Tappi J., 3, 7 (2004), https://www.tappi.org

17 T. Ikeda, S. Hosoya, Y. Tomimura, K. Magara and I. Takano, J. Wood Sci., 45, 233 (1999), https://doi.org/10.1007/BF01177731

18 A. Törngren and M. Ragner, Nord. Pulp Paper Res. J., 17, 179 (2002), https://doi.org/10.3183/npprj-200217-02-p179-182

19 D. Davies, T. Dietz and H. U. Suess, Pulp Pap. Canada, 110, 25 (2009)

20 D. Tavast, E. Brännvall, M. E. Lindström and G. Henriksson, Cellulose Chem. Technol., 45, 89 (2011), https://cellulosechemtechnol.ro/pdf/CCT1-

2(2011)/p.89-95.pdf

21 H. Zhang, S. Nie, C. Qin and S. Wang, Ind. Crop. Prod., 128, 338 (2019), https://doi.org/10.1016/j.indcrop.2018.11.025

22 K. M. M. Eiras and J. L. Colodette, J. Pulp Pap. Sci., 29, 64 (2003), https://pascalfrancis.inist.fr/vibad/index.php?action=getRecordDetai $1 \& i d t=14673907$

23 Y. Uchida, T. Miura and M. Iwasaki, in Procs. Tappi Pulping Conference, Orlando, FL, Tappi Press, Atlanta, 1999, pp. 317-322, https://www.tappi.org

24 T. Ikeda, S. Hosoya, Y. Tomimura, K. Magara, M. Ishihara et al., J. Wood Sci., 45, 417 (1999), https://doi.org/10.1007/BF01177915

25 D. Lachenal and C. Chirat, Tappi J., 83, 96 (2000), https://imisrise.tappi.org/TAPPI/Products/00/AUG/00 AUG96.aspx

26 H. Zhang, S. Nie, C. Qin, K. Zhang and S. Wang, Cellulose, $\quad$ 25, $2037 \quad$ (2018), https://doi.org/10.1007/s10570-018-1670-1

27 T. J. McDonough, S. Uno, A. W. Rudie and C. E. Courchene, Tappi J., 8, 10 (2009)

28 M. Ragnar, Appita J., 56, 471 (2003), https://pascal-

francis.inist.fr/vibad/index.php?action=getRecordDetai 1\&idt $=15352772$

29 J. L. Colodette and K. O. Henricson, in "The Bleaching of Pulp", edited by P. W. Hart, A. W. Rudie, $5^{\text {th }}$ ed., Tappi Press, Atlanta, 2012, pp. 103

30 T. Lehtimaa, V. Tarvo, S. Kuitunen, A. S. Jääskeläinen and T. Vuorinen, J. Wood Chem. Technol., $\quad 30, \quad 19 \quad$ (2010), https://doi.org/10.1080/02773810903276684

31 V. Tarvo, T. Lehtimaa, S. Kuitunen, V. Alopaeus, T. Vuorinen et al., J. Wood Chem. Technol., 30, 230 (2010), https://doi.org/10.1080/02773810903461476

32 D. Kaur, N. K. Bhardwaj and R. K. Lohchab, Cellulose, 26, 7469 (2019), https://doi.org/10.1007/s10570-019-02616-5

33 T. Ferdous, M. A. Quaiyyum and M. S. Jahan, Nord. Pulp Paper Res. J., (ahead-of-print) (2020), https://doi.org/10.1515/npprj-2020-0043 